2 型糖尿病患者のジペプチジルペプチダーゼ-4 阻害薬及びビグアナイド薬 に対する服薬頻度別のアドヒアランス及び関連因子

\author{
林 あい, ${ }^{a}$ 久保武一, ${ }^{a}$ 奥山ことば, $a$ 铇田 滋, ${ }^{a}$ 亀井美和子 $*, b$
}

\title{
Adherence to Oral Antihyperglycemic Agents (Dipeptidyl Peptidase-4 Inhibitors and Biguanides) and Its Associated Factors in Patients with Type 2 Diabetes
}

\author{
Ai Hayashi, ${ }^{a}$ Takekazu Kubo, ${ }^{a}$ Kotoba Okuyama, ${ }^{a}$ Shigeru Tokita, ${ }^{a}$ and Miwako Kamei ${ }^{*}, b$ \\ ${ }^{a}$ Medical Affairs, MSD K.K.; Kudan-kita 1-13-12, Chiyoda-ku, Tokyo 102-8667, Japan: and ${ }^{b}$ Laboratory of \\ Social and Administrative Pharmacy Science, School of Pharmacy, Nihon University; \\ Narashinodai 7-7-1, Funabashi, Chiba 274-8555, Japan.
}

(Received September 27, 2018; Accepted March 18, 2019)

\begin{abstract}
To investigate medication adherence to oral antihyperglycemic agents and its associated factors in Japanese type 2 diabetic patients, a questionnaire survey was conducted in 983 adult patients receiving once-daily (QD) or twice-daily (BID) dipeptidyl peptidase-4 inhibitors (DPP-4 inhibitor) or BID biguanides (BG) as monotherapy at 502 pharmacies in Japan. The percentage of patients with good adherence (the proportion of days in which patients took all pills as prescribed in the past 7 days $\geq 80 \%$ ) was high ( $\geq 90 \%$ ) in any dosing regimen with no significant difference among the groups. The following factors were identified as associating with good adherence: the longer duration of type 2 diabetes ( $\geq 1$ year) ( $p=0.002)$, "Feeling your disease gets worse if you don't take medications" $(p=0.031)$, "Not forgetting to bring along your medicine when you leave home" $(p=0.007)$, "Feeling anxiety on taking medications for long period of time" $(p=0.042)$, "Neither feeling nor not feeling anxiety on taking medications for a long period of time" $(p=0.004)$, "Never run out of your medicine because you get a refill on time" $(p=0.035)$, and the lower MMAS-4 score $(p<0.001)$. Subgroup analyses revealed that adherence of younger patients ( $<65$ years) with BG (BID) was lower than those with DPP-4 inhibitor (QD) $(p=0.021)$. Additionally, around $60 \%$ of patients currently prescribed with QD preferred QD regimen, and $\geq 80 \%$ patients prescribed with BID equally preferred once-weekly or QD regimen, suggesting a large discrepancy exists between their preference and the actual regimen in patients on BID.
\end{abstract}

Key words_ - type 2 diabetes mellitus; oral antihyperglycemic agent; medication adherence; dipeptidyl peptidase-4 inhibitor; biguanide

$$
\text { 緒 言 }
$$

糖尿病は，インスリン作用の不足による慢性の高 血糖状態を主徵とする代謝疾患群である.1）糖尿病 は成因により 1 型（自己免疫性，特発性）と 2 型 （インスリン分泌低下，インスリン抵抗性）の 2 種 類に大きく分類され，2 型が糖尿病の約 $90 \%$ を占め る. 1,2) 日本で主に処方される経口糖尿病薬には，ビ グアナイド（biguanide; BG）薬，スルホニル尿素 （sulfonylurea; SU） 薬， $\alpha$-グルコシダーゼ阻害 ( $\alpha$-glucosidase; $\alpha$-GI) 薬, チアゾリジン (thiazolidine; TZD) 薬, ジペプチジルペプチダーゼ-4

${ }^{a} \mathrm{MSD}$ 株式会社メディカルアフェアーズ, ${ }^{b}$ 日本大学薬 学部薬事管理学研究室

*e-mail: kamei.miwako@nihon-u.ac.jp （dipeptidyl peptidase-4; DPP-4）阻害薬，ナトリウ ム・グルコース共輸送体 2 (sodium glucose cotransporter 2; SGLT2) 阻害薬がある。欧米では BG 薬 のメトホルミンが第一選択薬として推奨されている が，日本では患者の病態に応じて最適な薬剤が選択 される.11)ただし近年では，血糖依存的にインスリ ン分泌を促す DPP-4 阻害薬の使用頻度が増加して おり, 臨床現場では 2 型糖尿病治療の第一選択薬に なりつつある. ${ }^{3,4)}$

長期にわたる慢性疾患の治療管理においては，処 方薬に対する良好な服薬アドヒアランスが重要であ る.これは 2 型糖尿病においても例外ではなく, 経 口糖尿病薬の服薬アドヒアランスが向上するほどへ モグロビン Alc (HbA1c) 值が低下し，良好な血 糖コントロールが得られることが報告されてい 
る. ${ }^{5,6)}$ 一方，服薬アドヒアランスが低い患者では， 血糖コントロールが悪化し易いだけでなく，入院リ スク及び死亡率が増大する傾向も認められてお り ${ }^{7,8)}$ 服薬アドヒアランスが血糖コントロールや疾 患の転帰に影響を及ぼす可能性が示唆されている. 一方，海外の報告によると，経口糖尿病薬を服用中 の患者のうち, 12 力月の平均処方薬剂保持率 (mean medication possession ratio; MPR) に基づ く服薬アドヒアランスが $80 \%$ を超える患者の割合 はわずか $58 \%$ であった. ${ }^{9)}$ 日本においても，糖尿病 患者の約 3 分の 2 が薬を飲文忘れたことがあると申 告しており, ${ }^{10)}$ 服薬アドヒアランスの改善は大きな 課題となっている，また海外の報告では，経口糖尿 病薬の服薬頻度が高くなると服薬アドヒアランスが 低下する, ${ }^{11)}$ 若しくは，若年の糖尿病患者及び女性 患者では服薬アドヒアランスが低いといつた ${ }^{12)}$ 知見 もあり, 薬剤並びに患者の背景因子がアドヒアラン スと関連することが示唆されている.

こうした背景から，服薬頻度別に 2 型糖尿病患者 の服薬行動の実態を明らかにし，アドヒアランス良 好又は不良につながる予測因子を特定することは， より患者にあわせた治療法を選択し実施する上で有 益と考えられる。しかし日本では，特に服薬頻度の 観点から, 経口糖尿病薬に対する服薬アドヒアラン スの挙動を確認した研究はほとんど存在しない。そ こで本研究では, 経口糖尿病薬の第一選択薬として 最もよく処方されるクラスである DPP-4 阻害薬又 は $\mathrm{BG}$ 薬を単剂服用中の 2 型糖尿病患者に対して患 者報告調查（patient-reported outcome; PRO）を実 施し，特に服薬頻度に注目して服薬アドヒアランス 並びに関連する因子の探索を行った。

\section{方法}

1. 調査対象患者現在日本の医療機関で受 診・治療中の 20 歳以上の 2 型糖尿病患者のうち,

DPP-4 阻害薬 [1 日 1 回 (QD) 又は 1 日 2 回 (BID)］又は BG 薬（BID）を血糖降下薬として単 剤で服用中の患者を調查対象とした。降圧剤や高脂 血症剤等，他の疾患に対する治療薬の併用は制限し ないこととした。対象薬として，DPP-4 阻害薬 （QD）にはシタグリプチン，アログリプチン，リ ナグリプチン，テネリグリプチン，及びサキサグリ プチンを，DPP-4 阻害薬（BID）にはビルダグリ
プチン及びアナグリプチンを， BG 薬にはメトホル ミン塩酸塩及びブホルミン塩酸塩を含めた。調査対 象者は，アンケート実施薬局において少なくとも 1 回の処方歴があり，対象薬を 30 日以上処方されて いることとした。

2. 調査期間 アンケート実施期間は，2017 年 5 月 15 日から 2017 年 10 月 6 日までとした.

3. 調査方法 調查実施薬局は，全国の薬局の 中から，処方元が診療所又は病院のいずれか，ま た，薬剤師会が公表している県別の処方箋枚数を， 日本 8 エリア（北海道地方・東北地方・関東地方 中部地方 - 近畿地方 $\cdot$ 中国地方 $\cdot$ 四国地方 $\cdot$ 九州沖 縄）毎に集計した分布と，調剤レセプトデータ上出 現した患者のエリア別分布をなるべく近しくなるよ う，薬局の選定を行つた．通常診療下で処方された 対象薬を受け取りに保険薬局に来局した調査対象候 補の患者に対して，事前に研修を受けた薬剤師が調 査参加への依頼を声掛けし，組み入れ条件のスク リーニングを実施した。事前の研修では，スクリー ニング実施方法，同意取得方法，アンケートの収集 手順，及び有害事象報告の手順等のマニュアルを用 いて，薬剤師への説明を行った。その上で調査への 同意が得られた患者に対し，質問票を用いた自己記 入式のアンケート調査を依頼した。患者による質問 票への記入（推定所要時間：約 5 分）は処方箋調剂 の待ち時間に行い，正直な記載を期す目的で質問票 は無記名とし，自ら封をしてもらい，担当薬剤師に 内容が開示されない状態でその場で回収した。調査 実施薬局の選定，薬剤師へのトレーニング，調査資 材の準備・提供，及びデー夕回収・分析について は，株式会社医療情報総合研究所（JMIRI）に委託 して実施した。本研究計画は，日本大学薬学部の倫 理審査委員会により審査され承認を得た。

4. 調査内容調查参加者に配布したアンケー 卜用紙を Fig. 1 に示す。調查項目は，患者の属性 に関する項目 (年齢, 性別, 罹病期間, 服薬期間, 職業, 最終学歴, 同居人の有無), 服薬状況に関す る項目（過去 7 日間及び 30 日間の飲み残し日数）, 服薬アドヒアランスに影響を及ぼすと考えられる因 子に関する項目（服薬に対する意識，薬や病気に対 する考え方，食事・運動療法への取り組み，食事習 慣，医療者に対する信頼，市販薬の利用有無と頻 度，希望する服薬頻度，ブラウンバッグ・携帯アプ 


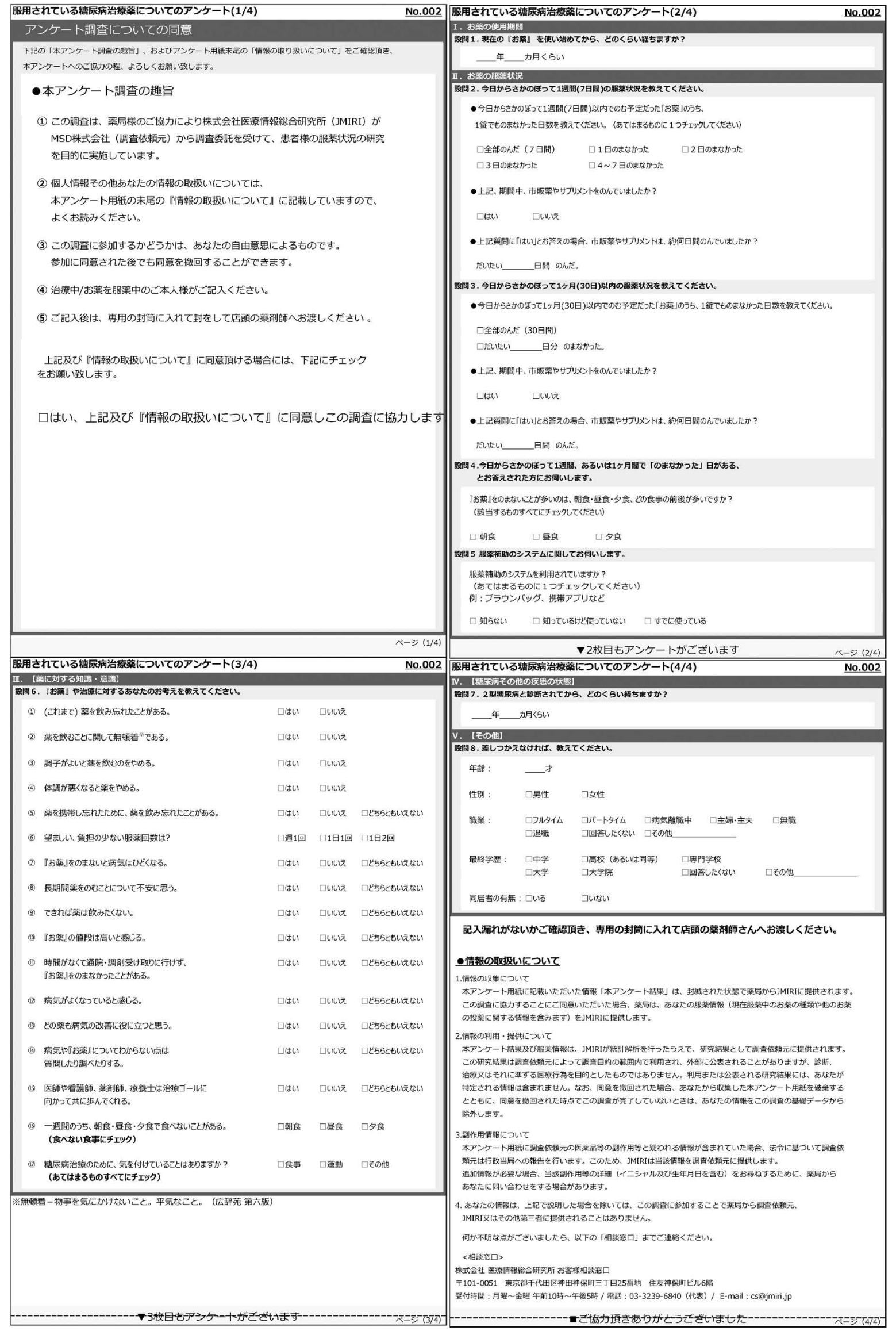

Fig. 1. Questionnaire Sheet 
リケーションなどの服薬支援プログラムの利用）と した.

服薬アドヒアランスの評価には proportion of days completely covered（PDCC：過去 7 日間又は 30 日間で，処方薬を指示通りに 1 錠の飲み忘れも なく飲めた日数の割合）を用い，さらに服薬行動の 指標として Morisky Medication Adherence Scale-4 (MMAS-4) 13) を用いた。過去 7 日間及び 30 日間の 服薬アドヒアランス評価では, 飲み残しがあった日 数から PDCC を算出し, PDCC が $80 \%$ 以上を「ア ドヒアランス良好」, $80 \%$ 未満を「アドヒアランス 不良」とした。ささに，アドヒアランスが良好で あった患者の割合（以下，アドヒアランス良好率） を患者全体又は治療レジメン群［DPP-4 阻害薬 (QD)，DPP-4 阻害薬（BID)，BG 薬 (BID)] 毎 に算出した。 MMAS-4による服薬行動の評価で は，アンケート用紙の設問 6 （Fig. 1）に記載され た 4 つの質問（「薬を飲み忘れたことがある」，「薬 をのむことに関して無頓着である」，「調子がよいと 薬をのむのをやめる」,「体調が悪くなると薬をやめ る」）に対する回答に基づき，「いいえ」を 0 点, 「はい」を 1 点として合計スコア $(0-4:$ 低值ほどア ドヒアランス良好）を算出した。

アドヒアランス良好又は不良に関連する因子は, 患者全体又は治療レジメン群毎に解析した。解析対 象因子として，患者関連因子及び薬剂関連因子を設 定した。患者関連因子は, 年齢, 性別, 罹病期間, 職業, 最終学歴, 同居人の有無, 食事・運動療法へ の取り組み, その他療法の併用, 病識・薬識（薬を のまないと病気がひどくなると考える, 病気がよく なつていると感じる, 薬は病気の改善に役に立つと 考える), 服薬へのモチベーション要因（薬の携帯 忘れによるのみ忘れ，長期使用に対する不安，薬の のみたくなさ），医療関係者の支援（治療ゴールに 向かって共に歩んでくれていると感じる）とした.

薬剂関連因子は，薬剤クラス，DPP-4 阻害薬又は BG 薬の処方期間, 経済的負担（薬の值段が高いと 感じる)，時間的制約（時間がなくて病院や薬局に 行けず薬をのまなかったことはある), 薬識（病気 や薬について自主的に質問したり調べたりする),

食事習慣（1 週間で 3 食のうち食べない夕イミン グ), 希望する服薬頻度, MMAS-4, 対象薬服薬期 間中の市販薬やサプリメントの利用有無と頻度, ブ
ラウンバッグ・携帯アプリケーションなどの服薬支 援プログラムの利用とした。

\section{5. 統計解析 過去 7 日間及び 30 日間のアド} ヒアランス良好率を治療レジメン群間で比較するた め, 多変量ロジスティック回帰分析を行い, 各群の アドヒアランス良好率を推定し，群間の差をオッズ 比，95\%信頼区間，及び $p$ 值を用いて評価した。 MMAS-4 スコアの群間比較では, MMAS-4 スコア を連続量として多変量線形回帰分析を実施し, 各群 の平均スコアを推定し，回帰係数，標準誤差，及び $p$ 值を算出した。過去 7 日間及び 30 日間のアドヒ アランス良好に関連する因子は多変量ロジスティッ ク回帰分析により探索し，オッズ比，95\%信頼区 間，及び $p$ 值を用いて評価した。 MMAS-4 スコア 低值に関連する因子は多変量線形回帰分析により探 索し, 回帰係数, 標準誤差, 及び $p$ 值を用いて評 価した. 多変量ロジスティック回帰分析によるサブ グループ解析を行い，各サブグループにおける過去 7 日間のアドヒアランス良好率を治療レジメン群間 で比較した，多変量解析では，治療レジメンを説明 変数として常にモデルに加え，各変数の効果の $p$ 值が最大のものから順次除いていく変数減少法を採 用した．欠測值には多重補完法を用いた．統計学的 有意水準はいずれの場合も両側 $5 \%$ とし，治療レジ メン間の群間比較では, 多重性の調整は実施しな かった.

\section{結果}

1. 症例構成本調查の症例構成を Fig. 2 に示 す。薬剤師によるスクリーニングの結果, 組み入れ 基準を満たした調査参加者候補 1149 例のうち, 1019 例にアンケートが配布され，1016 例から回答 を得た。このうち, 飲み残し日数未記載の 32 例及 び 20 歳未満の 1 例を除く 983 例を解析対象とした。

なお, 調査実施薬局の総数は 502 店舗であり, 病 院を主な処方元とする薬局が $52 \%$, 診療所を主な 処方元とする薬局が $48 \%$ であつた．立地について は, 門前薬局 $[1$ つの医療機関からの処方箋の集中 率が高い（8 割超）保険薬局］が 84\%を占めた。所 在地については，関東が $50 \%$, 近畿が $17 \%$ ，その 他の地域はそれぞれ 2-8\%であった。

2. 患者背景 患者背景を Table 1 に示す。解 析対象患者 983 例のうち, DPP-4 阻害薬 (QD) 


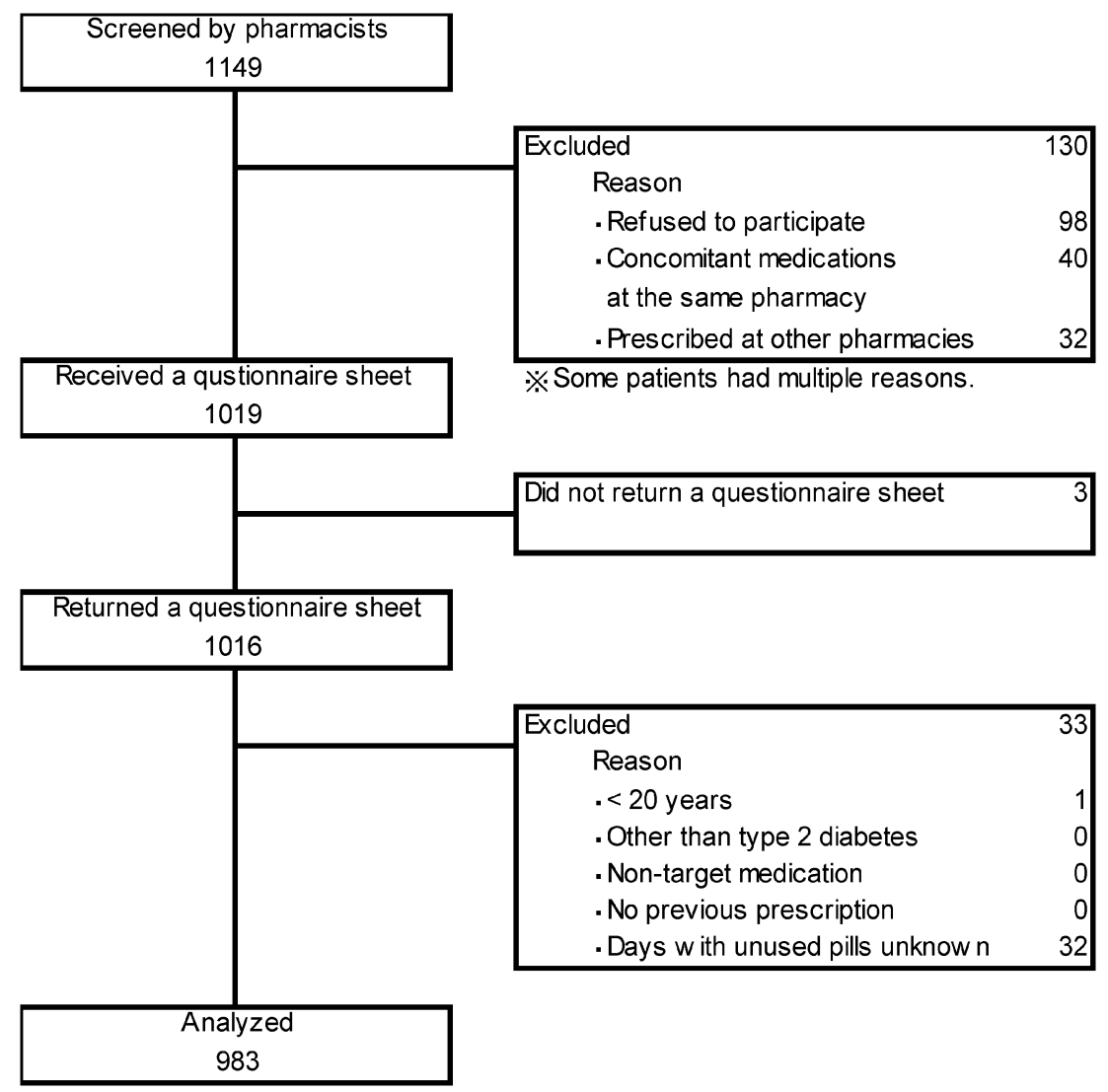

Fig. 2. Patient Disposition

[以下，DPP-4 (QD) ] を服用中の患者は 725 例, DPP-4 阻害薬（BID） [以下, DPP-4 (BID)] は 124 例, BG 薬（BID） [以下, BG (BID)] は 134 例であった.

患者全体の平均年齢は $60.8 \pm 13.0$ 歳（平均 \pm 標 準偏差, 以下同）で， 20 歳以上 65 歳未満の非高齢 者が $57.3 \% ， 65$ 歳以上の高齢者が $40.2 \%$ を占め た。男性は $59.4 \%$ ，女性は $38.6 \%$ あった。罹病 期間の平均は $4.9 \pm 4.5$ 年で, 1 年以上が $83.4 \%$ を 占めた。調査対象薬の服薬期間の平均は $27.8 \pm$ 24.3 力月で, 6 力月以上が $78.9 \%$ 占めた. 就労 者は $44.2 \%$ 占め, その大半がフルタイム就労者

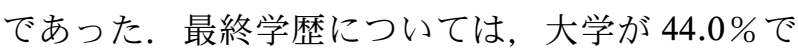
最も多く，ついで高校が $31.8 \%$ であつた。同居者 の有無では，同居者ありが $79.1 \%$ を占めた.

これらの患者属性について治療レジメン群間で大 きく異なる点は認められなかった，ただし，DPP-4 (BID) では, 平均年齢がやや低く $(57.0 \pm 11.9$ 歳 $)$,

20 歳以上 65 歳未満の非高齢者がやや多く, $70.2 \%$ を占めた。さらに，同治療レジメン群では罹病期間
の平均が $3.9 \pm 3.4$ 年と全体より約 1 年短く, 服薬 期間の平均は $21.5 \pm 29.4$ 力月と全体より約 6 力月 短かった。 また, 就労者の割合は $55.6 \%$ と全体と 比較してやや高い傾向が認められた.

3. 過去 7 日間の服薬頻度別のアドヒアランス 過去 7 日間のアドヒアランスを評価するため, PDCC に基づくアドヒアランス良好率を算出し, 治療レジメン群間で比較した（Table 2)。過去 7 日 間のアドヒアランス良好率は，DPP-4 (QD) で 96.3\%, DPP-4 (BID) で 96.0\%, BG (BID) で $94.8 \%$ とすべての治療レジメン群で高く, 群間で有 意差は認められなかった。

次に, 多変量ロジスティック回帰分析により過去 7 日間のアドヒアランス良好と関連する因子を検討 したところ，「罹病期間が 1 年以上」，「『お薬』をの まないと病気がひどくなる，と考える」，「薬を携帯 し忘れたために，薬をのみ忘れたことがない」，「長 期間薬をのむことについて不安に思う」及び「不安 があるか，どちらともいえない」，「時間がなくて通 院・調剤を受け取りに行けず，『お薬』をのまな 
Table 1. Patient Characteristics

\begin{tabular}{|c|c|c|c|c|c|}
\hline & & $\begin{array}{c}\text { Total } \\
N=983\end{array}$ & $\begin{array}{c}\text { DPP-4（QD） } \\
\quad N=725\end{array}$ & $\begin{array}{c}\text { DPP-4 (BID) } \\
N=124\end{array}$ & $\begin{array}{c}\text { BG (BID) } \\
N=134\end{array}$ \\
\hline \multirow{4}{*}{$\begin{array}{l}\text { Age }(\mathrm{yr}), \text { Mean } \pm \text { S.D. } \\
\quad \text { Category, } n(\%)\end{array}$} & & $60.8 \pm 13.0$ & $61.0 \pm 13.0$ & $57.0 \pm 11.9$ & $63.1 \pm 13.0$ \\
\hline & $20 \mathrm{yr} \leq,<65 \mathrm{yr}$ & $563(57.3)$ & $406(56.0)$ & $87(70.2)$ & $70(52.2)$ \\
\hline & $65 \mathrm{yr} \leq$ & $395(40.2)$ & $298(41.1)$ & $34(27.4)$ & $63(47.0)$ \\
\hline & Unknown & $25(2.5)$ & $21(2.9)$ & $3(2.4)$ & $1(0.7)$ \\
\hline \multirow[t]{3}{*}{ Sex, $n(\%)$} & Male & $584(59.4)$ & $432(59.6)$ & $79(63.7)$ & $73(54.5)$ \\
\hline & Female & $379(38.6)$ & $277(38.2)$ & $42(33.9)$ & $60(44.8)$ \\
\hline & Unknown & $20(2.0)$ & $16(2.2)$ & $3(2.4)$ & $1(0.7)$ \\
\hline \multicolumn{2}{|c|}{ Duration of disease (yr), Mean \pm S.D. } & $4.9 \pm 4.5$ & $4.9 \pm 4.6$ & $3.9 \pm 3.4$ & $5.9 \pm 4.6$ \\
\hline \multirow[t]{3}{*}{ Category, $n(\%)$} & $<1 \mathrm{yr}$ & $67(6.8)$ & $42(5.8)$ & $12(9.7)$ & $13(9.7)$ \\
\hline & $1 \mathrm{yr} \leq$ & $820(83.4)$ & $607(83.7)$ & $100(80.6)$ & $113(84.3)$ \\
\hline & Unknown & $96(9.8)$ & $76(10.5)$ & $12(9.7)$ & $8(6.0)$ \\
\hline \multicolumn{2}{|c|}{ Prescribed duration (mo), Mean \pm S.D. } & $27.8 \pm 24.3$ & $28.3 \pm 23.0$ & $21.5 \pm 29.4$ & $30.7 \pm 25.0$ \\
\hline \multirow[t]{3}{*}{ Category, $n(\%)$} & $<6 \mathrm{mo}$ & $60(6.1)$ & $41(5.7)$ & $7(5.6)$ & $12(9.0)$ \\
\hline & $6 \mathrm{mo} \leq$ & $776(78.9)$ & $562(77.5)$ & $104(83.9)$ & $110(82.1)$ \\
\hline & Unknown & $147(15.0)$ & $122(16.8)$ & $13(10.5)$ & $12(9.0)$ \\
\hline \multirow[t]{10}{*}{ Occupation, $n(\%)$} & Employed & $434(44.2)$ & $313(43.2)$ & $69(55.6)$ & $52(38.8)$ \\
\hline & Full-time & $343(34.9)$ & $246(33.9)$ & $51(41.1)$ & $46(34.3)$ \\
\hline & Part-time & $91(9.3)$ & $67(9.2)$ & $18(14.5)$ & $6(4.5)$ \\
\hline & Long-term sick leave & $1(0.1)$ & $0(0.0)$ & $1(0.8)$ & $0(0.0)$ \\
\hline & Homemaker & $229(23.3)$ & $175(24.1)$ & $20(16.1)$ & $34(25.4)$ \\
\hline & Unemployed & $186(18.9)$ & $144(19.9)$ & $14(11.3)$ & $28(20.9)$ \\
\hline & Retired & $49(5.0)$ & $32(4.4)$ & $6(4.8)$ & $11(8.2)$ \\
\hline & Prefer not to answer & $2(0.2)$ & $2(0.3)$ & $0(0.0)$ & $0(0.0)$ \\
\hline & Others & $38(3.9)$ & $28(3.9)$ & $7(5.6)$ & $3(2.2)$ \\
\hline & Unknown & $44(4.5)$ & $31(4.3)$ & $7(5.6)$ & $6(4.5)$ \\
\hline \multirow[t]{8}{*}{ Education, $n(\%)$} & Middle school & $63(6.4)$ & $45(6.2)$ & $10(8.1)$ & $8(6.0)$ \\
\hline & High school & $313(31.8)$ & $222(30.6)$ & $39(31.5)$ & $52(38.8)$ \\
\hline & Technical school & $70(7.1)$ & $54(7.4)$ & $10(8.1)$ & $6(4.5)$ \\
\hline & College & $433(44.0)$ & $322(44.4)$ & $56(45.2)$ & $55(41.0)$ \\
\hline & Graduate school & $54(5.5)$ & $41(5.7)$ & $5(4.0)$ & $8(6.0)$ \\
\hline & Prefer not to answer & $12(1.2)$ & $10(1.4)$ & $0(0.0)$ & $2(1.5)$ \\
\hline & Others & $4(0.4)$ & $3(0.4)$ & $1(0.8)$ & $0(0.0)$ \\
\hline & Unknown & $34(3.5)$ & $28(3.9)$ & $3(2.4)$ & $3(2.2)$ \\
\hline \multirow[t]{3}{*}{ Housemate, $n(\%)$} & No & $159(16.2)$ & $115(15.9)$ & $25(20.2)$ & $19(14.2)$ \\
\hline & Yes & $778(79.1)$ & $571(78.8)$ & $94(75.8)$ & $113(84.3)$ \\
\hline & Unknown & $46(4.7)$ & $39(5.4)$ & $5(4.0)$ & $2(1.5)$ \\
\hline
\end{tabular}

DPP-4: dipeptidyl peptidase-4 inhibitor, BG: biguanide, QD: once daily, BID: twice daily, yr: year, mo: month.

かったことがない」，及び「MMAS-4 スコアがより 低い」で正の関連が認められた（Table 2).

さらに，それぞれの解析対象因子についてサブグ ループ解析を実施したところ, 20 歳以上 65 歳未満 の非高齢者では DPP-4（QD）に比べて BG（BID） でアドヒアランス良好率が有意に低く，DPP-4 （BID）でも低い傾向がみられた（ $p=0.063 ） （ \mathrm{Ta}-$ ble 3). また, 経済的負担を感じないサブグループ
では，DPP-4（QD）に比べて BG（BID）でアド ヒアランス良好率が有意に低かった。

4. 過去 30 日間の服薬頻度別のアドヒアランス 過去 7 日間のアドヒアランス良好率と同様に，過 去 30 日間のアドヒアランス良好率は $97.9 \%$ であ り，すべての治療レジメン群で高く [DPP-4（QD） (97.9\%), DPP-4 (BID) (99.2\%), BG (BID) (96.3 \%)]，群間で差は認められなかった。また推定アド 
Table 2. Factors Related to Good Adherence in the Past 7 Days

\begin{tabular}{|c|c|c|c|c|c|c|}
\hline \multirow[t]{2}{*}{ Item } & \multirow[t]{2}{*}{ Category } & \multirow[t]{2}{*}{$N$} & \multirow{2}{*}{$\begin{array}{c}\text { Good ADH } \\
n(\%)\end{array}$} & \multirow{2}{*}{$\begin{array}{c}\text { Estimated } \\
\text { Good ADH } \\
(\%)\end{array}$} & \multicolumn{2}{|c|}{$\begin{array}{l}\text { Multivariable logistic } \\
\text { regression analysis }\end{array}$} \\
\hline & & & & & Odds ratio $(95 \% \mathrm{CI})$ & $p$-value \\
\hline Total & & 983 & $944(96.0)$ & & - & \\
\hline \multirow[t]{3}{*}{ Regimen } & DPP-4（QD） & 725 & $698(96.3)$ & 99.95 & - & \\
\hline & DPP-4（BID） & 124 & $119(96.0)$ & 99.94 & $0.78(0.25-2.42)$ & $p=0.673$ \\
\hline & BG（BID） & 134 & $127(94.8)$ & 99.94 & $0.80(0.29-2.24)$ & $p=0.672$ \\
\hline \multirow[t]{2}{*}{ Duration of disease } & $<1 \mathrm{yr}$ & 67 & $60(89.6)$ & 99.87 & - & - \\
\hline & $1 \mathrm{yr} \leq$ & 820 & $795(97.0)$ & 99.97 & $5.12(1.85-14.16)$ & $p=0.002$ \\
\hline \multirow[t]{4}{*}{ Diet and exercise therapy } & No & 70 & $68(97.1)$ & 99.97 & - & - \\
\hline & Diet only & 274 & $262(95.6)$ & 99.96 & $0.69(0.12-3.98)$ & $p=0.682$ \\
\hline & Exercise only & 86 & $77(89.5)$ & 99.81 & $0.16(0.02-1.03)$ & $p=0.054$ \\
\hline & Both & 553 & $537(97.1)$ & 99.96 & $0.74(0.14-4.06)$ & $p=0.729$ \\
\hline \multirow{3}{*}{$\begin{array}{l}\text { Disease and drug literacy } \\
\text { "Symptoms get worse if drug is } \\
\text { not taken" }\end{array}$} & No & 318 & $297(93.4)$ & 99.88 & - & - \\
\hline & Yes & 96 & $93(96.9)$ & 99.98 & $5.35(1.17-24.58)$ & $p=0.031$ \\
\hline & Neutral $^{a}$ & 559 & $544(97.3)$ & 99.93 & $1.76(0.74-4.15)$ & $p=0.198$ \\
\hline \multirow{3}{*}{$\begin{array}{l}\text { Motivation toward medication } \\
\text { "Missed doses due to not car- } \\
\text { rying drugs"' }\end{array}$} & No & 653 & $642(98.3)$ & 99.98 & - & - \\
\hline & Yes & 260 & $237(91.2)$ & 99.92 & $0.29(0.12-0.71)$ & $p=0.007$ \\
\hline & Neutral $^{\mathrm{a}}$ & 60 & $57(95.0)$ & 99.90 & $0.22(0.03-1.48)$ & $p=0.116$ \\
\hline \multirow{3}{*}{$\begin{array}{l}\text { Motivation toward medication } \\
\text { "Anxiety toward long-term } \\
\text { use", }\end{array}$} & No & 398 & $373(93.7)$ & 99.85 & - & - \\
\hline & Yes & 277 & $267(96.4)$ & 99.94 & $2.61(1.03-6.58)$ & $p=0.042$ \\
\hline & Neutral $^{\mathrm{a}}$ & 303 & $299(98.7)$ & 99.98 & $6.77(1.82-25.22)$ & $p=0.004$ \\
\hline \multirow{3}{*}{$\begin{array}{l}\text { Time constraint } \\
\text { "Missed doses due to a lack of } \\
\text { time to refill" }\end{array}$} & No & 731 & $703(96.2)$ & 96.90 & - & - \\
\hline & Yes & 73 & $62(84.9)$ & 91.89 & $0.36(0.14-0.93)$ & $p=0.035$ \\
\hline & Neutral $^{a}$ & 167 & $167(100.0)$ & 100.00 & $\mathrm{~N} / \mathrm{A}$ & $\mathrm{N} / \mathrm{A}$ \\
\hline \multicolumn{2}{|l|}{ MMAS-4 score (continuous value) } & 970 & $931(96.0)$ & - & $0.49(0.32-0.75)$ & $p<0.001$ \\
\hline \multirow{3}{*}{$\begin{array}{l}\text { Adherence program } \\
\text { "Do you know any adherence } \\
\text { program available?" }\end{array}$} & No & 173 & $168(97.1)$ & 99.94 & - & - \\
\hline & Yes, but not using & 609 & $576(94.6)$ & 99.86 & $0.44(0.15-1.32)$ & $p=0.144$ \\
\hline & Already using & 186 & $185(99.5)$ & 99.98 & $2.79(0.30-26.24)$ & $p=0.370$ \\
\hline
\end{tabular}

a Neither agree nor disagree. ADH: adherence, CI: confidence interval, yr: year, DPP-4: dipeptidyl peptidase-4 inhibitor, BG: biguanide, QD: once daily, BID: twice daily, MMAS-4: Morisky medication adherence scale-4. Use of the C) MMAS is protected by US and International copyright laws. Permission for use is required. A license agreement is available from: MMAS Research LLC 14725 NE 20th St. Bellevue WA 98007. Trubow1@gmail.com or dmorisky@gmail.com.

ヒアランス良好率も 3 群すべてにおいて高值で あった [DPP-4 (QD) $(99.79 \%) ， D P P-4 \quad(B I D)$ $(99.90 \%)$, BG (BID) $(99.79 \%)]$ (Table 4).

次に，多変量ロジスティック回帰分析により過去 30 日間のアドヒアランス良好と関連する因子を検 討したところ,「その他療法への取り組みがある」, 「食事を 2 食抜かない」,「薬を携帯し忘れたために, 薬をのみ忘れたことがない」，「時間的制約がない」 で正の関連が認められた（Table 4).

良好な服薬行動の 1 つの指標とされる「MMAS4 スコアがより低い」は関連する因子として検出さ れなかった。 また, 関連因子のサブグループ解析で は，いずれの因子においても有意差は認められな
かった.

5. MMAS-4による服薬行動評価服薬行動 の指標である MMAS-4 スコアを多変量線形回帰分 析により治療レジメン群間で比較したところ，平均 スコアは DPP-4（QD） で $1.0 \pm 0.93 ，$ DPP-4 (BID) で $0.8 \pm 0.92$, BG (BID) で $1.0 \pm 1.01$ と いずれの治療レジメン群においても低值で, 群間で 有意差は認められなかった（Table 5).

多変量線形回帰分析により MMAS-4 スコア低值 （すなわち，アドヒアランス良好）と関連する因子 を探索したところ,「年齢が 45 歳以上 65 歳未満」 (「年齢が 65 歳以上は低值の傾向 $[p=0.054]$ ), 「最終学歴が高くない」，「食事を 1 食あるいは 2 食 
Table 3. Subgroup Analysis of Adherence Rate in the Past 7 Days

\begin{tabular}{|c|c|c|c|c|c|c|}
\hline \multirow[t]{2}{*}{ Subgroup } & \multirow[t]{2}{*}{ Regimen } & \multirow[t]{2}{*}{$N$} & \multirow{2}{*}{$\begin{array}{c}\text { Good ADH } \\
n(\%)\end{array}$} & \multirow{2}{*}{$\begin{array}{c}\text { Estimated } \\
\text { Good ADH } \\
(\%)\end{array}$} & \multicolumn{2}{|c|}{$\begin{array}{l}\text { Multivariable logistic } \\
\text { regression analysis }\end{array}$} \\
\hline & & & & & Odds ratio $(95 \% \mathrm{CI})$ & $p$-value \\
\hline \multicolumn{7}{|l|}{ Age } \\
\hline \multirow[t]{3}{*}{$20 \mathrm{yr} \leq,<65 \mathrm{yr}$} & DPP-4（QD） & 406 & $397(97.8)$ & 99.96 & - & - \\
\hline & DPP-4（BID） & 87 & $82(94.3)$ & 99.86 & $0.27(0.07-1.07)$ & $p=0.063$ \\
\hline & BG（BID） & 70 & $63(90.0)$ & 99.82 & $0.21(0.06-0.79)$ & $p=0.021$ \\
\hline \multirow[t]{3}{*}{$65 \mathrm{yr} \leq$} & DPP-4（QD） & 298 & $283(95.0)$ & 100.00 & - & - \\
\hline & DPP-4（BID） & 34 & $34(100.0)$ & 100.00 & $\mathrm{~N} / \mathrm{A}$ & $\mathrm{N} / \mathrm{A}$ \\
\hline & BG（BID） & 63 & $63(100.0)$ & 100.00 & $\mathrm{~N} / \mathrm{A}$ & $\mathrm{N} / \mathrm{A}$ \\
\hline \multicolumn{7}{|c|}{ Disease and drug literacy "Do you feel that your condition is getting better?" } \\
\hline \multirow[t]{3}{*}{ No } & DPP-4（QD） & 105 & $101(96.2)$ & 100.00 & - & - \\
\hline & DPP-4（BID） & 26 & $25(96.2)$ & 100.00 & $0.11(0.00-9.00)$ & $p=0.323$ \\
\hline & BG（BID） & 17 & $16(94.1)$ & 100.00 & $0.10(0.00-12.79)$ & $p=0.351$ \\
\hline \multirow[t]{3}{*}{ Yes } & DPP-4（QD） & 263 & $256(97.3)$ & 100.00 & - & \\
\hline & DPP-4 (BID) & 46 & $43(93.5)$ & 100.00 & $0.08(0.01-0.84)$ & $p=0.035$ \\
\hline & BG（BID） & 46 & $43(93.5)$ & 100.00 & $0.52(0.06-4.68)$ & $p=0.557$ \\
\hline \multirow[t]{3}{*}{ Neutral $^{\mathrm{a}}$} & DPP-4（QD） & 354 & $338(95.5)$ & 99.86 & - & \\
\hline & DPP-4（BID） & 52 & $51(98.1)$ & 99.96 & $3.59(0.41-31.34)$ & $p=0.248$ \\
\hline & BG（BID） & 71 & $68(95.8)$ & 99.91 & $1.51(0.37-6.16)$ & $p=0.568$ \\
\hline \multicolumn{7}{|c|}{ Economic burden on co-pay } \\
\hline \multirow[t]{3}{*}{ No } & DPP-4（QD） & 116 & $113(97.4)$ & 100.00 & - & - \\
\hline & DPP-4 (BID) & 29 & $26(89.7)$ & 100.00 & $0.02(0.00-4.05)$ & $p=0.145$ \\
\hline & BG（BID） & 30 & $24(80.0)$ & 100.00 & $0.03(0.00-0.93)$ & $p=0.045$ \\
\hline \multirow[t]{3}{*}{ Yes } & DPP-4（QD） & 462 & $445(96.3)$ & 99.93 & - & - \\
\hline & DPP-4（BID） & 67 & $65(97.0)$ & 99.95 & $1.42(0.25-8.03)$ & $p=0.690$ \\
\hline & BG（BID） & 67 & $66(98.5)$ & 99.97 & $2.37(0.27-20.57)$ & $p=0.432$ \\
\hline \multirow[t]{3}{*}{ Neutral $^{a}$} & DPP-4（QD） & 137 & $131(95.6)$ & 100.00 & - & - \\
\hline & DPP-4（BID） & 28 & $28(100.0)$ & 100.00 & $\mathrm{~N} / \mathrm{A}$ & N/A \\
\hline & BG（BID） & 37 & $37(100.0)$ & 100.00 & $\mathrm{~N} / \mathrm{A}$ & $\mathrm{N} / \mathrm{A}$ \\
\hline
\end{tabular}

a Neither agree nor disagree. ADH: adherence, CI: confidence interval, yr: year, DPP-4: dipeptidyl peptidase-4 inhibitor, BG: biguanide, QD: once daily, BID: twice daily.

抜かない」、「病気がよくなつていると感じる“どち らでもない”,「薬の携帯忘れによるのみ忘れをし ない」,「長期間薬をのむことについて不安に思わな い」,「できれば薬はのみたくない“どちらでもな い”」,「医師や看護師, 薬剤師, 療養士は治療ゴー ルに向かって共に歩んでくれる“どちらでもな い”」「時間的制約がない」，「OTCの服薬日数割合 (過去 7 日間）が高い」，「OTC の服薬日数割合（過 去 30 日間）が低い」，「服薬補助のシステムを利用 されていますか? “知らない”」が検出された（Table 5).

\section{6. 希望する服薬頻度 経口糖尿病薬の希望す}

る服薬頻度を治療レジメン群毎に調査したところ， DPP-4（QD）を服用中の患者の約 6 割は 1 日 1 回 （QD）を希望し， 3 割が 1 週間 1 回（QW）を希望 した。一方，1日 2 回（BID）を服用中の患者は， 約 4 割が 1 日 1 回（QD）を，残り約 4 割が 1 週間 1 回（QW）を希望し，1日2回（BID）を希望す る患者は 2 割未満であったことから，BID で服用 中の患者では, 服薬頻度について現状と患者の希望 が乘離していることが示された（Table 6).

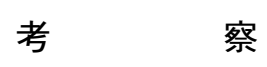

本研究では, 日本人 2 型糖尿病患者における経口 
Table 4. Factors Related to Good Adherence in the Past 30 Days

\begin{tabular}{|c|c|c|c|c|c|c|}
\hline \multirow[t]{2}{*}{ Item } & \multirow[t]{2}{*}{ Category } & \multirow[t]{2}{*}{$N$} & \multirow{2}{*}{$\begin{array}{c}\text { Good ADH } \\
n(\%)\end{array}$} & \multirow{2}{*}{$\begin{array}{c}\text { Estimated } \\
\text { Good ADH } \\
(\%)\end{array}$} & \multicolumn{2}{|c|}{$\begin{array}{l}\text { Multivariable logistic } \\
\text { regression analysis }\end{array}$} \\
\hline & & & & & Odds ratio $(95 \% \mathrm{CI})$ & $p$-value \\
\hline Total & & 982 & $961(97.9)$ & & - & \\
\hline \multirow[t]{3}{*}{ Regimen } & DPP-4 (QD) & 725 & $710(97.9)$ & 99.79 & - & \\
\hline & DPP-4（BID） & 123 & $122(99.2)$ & 99.90 & $2.13(0.22-20.68)$ & $p=0.514$ \\
\hline & BG（BID） & 134 & $129(96.3)$ & 99.79 & $0.97(0.25-3.72)$ & $p=0.965$ \\
\hline \multirow[t]{4}{*}{ Diet and exercise therapy } & No & 70 & $69(98.6)$ & 99.82 & - & - \\
\hline & Diet only & 273 & $263(96.3)$ & 99.80 & $0.89(0.09-8.44)$ & $p=0.922$ \\
\hline & Exercise only & 86 & $81(94.2)$ & 99.56 & $0.40(0.03-4.55)$ & $p=0.458$ \\
\hline & Both & 553 & $548(99.1)$ & 99.95 & $3.76(0.34-41.26)$ & $p=0.278$ \\
\hline \multirow[t]{2}{*}{ Other therapies } & No & 523 & $506(96.8)$ & 99.49 & - & - \\
\hline & Yes & 459 & $455(99.1)$ & 99.95 & $10.01(1.20-83.54)$ & $p=0.033$ \\
\hline \multirow[t]{4}{*}{ Diet habit (skip meals) } & No & 532 & $524(98.5)$ & 98.56 & - & - \\
\hline & 1 meal & 336 & $327(97.3)$ & 98.57 & $1.01(0.30-3.37)$ & $p=0.989$ \\
\hline & 2 meals & 105 & $101(96.2)$ & 79.88 & $0.06(0.00-0.69)$ & $p=0.025$ \\
\hline & 3 meals & 9 & $9(100.0)$ & 100.00 & $\mathrm{~N} / \mathrm{A}$ & $\mathrm{N} / \mathrm{A}$ \\
\hline \multirow{3}{*}{$\begin{array}{l}\text { Motivation toward medication } \\
\text { "Missed doses due to not car- } \\
\text { rying drugs" }\end{array}$} & No & 653 & $651(99.7)$ & 99.96 & - & - \\
\hline & Yes & 260 & $243(93.5)$ & 99.44 & $0.07(0.01-0.34)$ & $p=0.001$ \\
\hline & Neutral $^{a}$ & 59 & $58(98.3)$ & 99.79 & $0.17(0.01-2.28)$ & $p=0.182$ \\
\hline \multirow{3}{*}{$\begin{array}{l}\text { Time constraint } \\
\text { "Missed doses due to a lack of } \\
\text { time to refill" }\end{array}$} & No & 730 & $721(98.8)$ & 99.94 & - & - \\
\hline & Yes & 73 & $65(89.0)$ & 99.57 & $0.14(0.04-0.49)$ & $p=0.002$ \\
\hline & Neutral $^{\mathrm{a}}$ & 167 & $164(98.2)$ & 99.83 & $0.35(0.05-2.22)$ & $p=0.259$ \\
\hline
\end{tabular}

a Neither agree nor disagree. ADH: adherence, CI: confidence interval, DPP-4: dipeptidyl peptidase-4 inhibitor, BG: biguanide, QD: once daily, BID: twice daily.

糖尿病薬の服薬行動を服薬頻度別のアドヒアランス から明らかにするため, DPP-4 [(QD) 又は (BID) ] 又は BG（BID）を単剤服用中の患者を対象にアン ケート調查を実施した。患者属性について治療レジ メン群間で大きく異なる点は認められなかったが, DPP-4（BID）では 20 歳以上 65 歳未満の非高齢者 が比較的多く, その影響からか罹病期間が短く, 就 労者の割合がやや高い傾向がみられた.

服薬アドヒアランスの評価に用いられる指標の 1 つである proportion of days covered（PDC：対象 薬の処方日数を調査対象期間の日数で除した割合） を用いて日本の 2 型糖尿病患者の服薬アドヒアラン スを調査した先行研究では, DPP-4 阻害薬の単剤 療法を受けている患者の $67.2 \%, 2$ 剂併用療法を受 けている患者の $74.6 \%$ でアドヒアランス良好（1 年

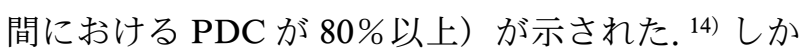
し，PDCによる解析では，調剤されたが服用され なかつた錠剤の有無や飲み忘れを検出することがで きないため, 服薬アドヒアランスを過大評価してい
る可能性がある，そこで本研究では，患者の自己報 告に基づき，飲み忘れを 1 回もしなかつた日数の割 合（PDCC）を用いて服薬頻度別のアドヒアランス を評価した。その結果，過去 7 日間のアドヒアラン ス良好率は治療レジメンにかかわらず $90 \%$ を超え ることが示された。 2 型糖尿病を始めとする慢性疾 患では, 経口薬の服薬回数が増えるほど服薬アドヒ アランスが低下する傾向が指摘されている. ${ }^{15-17)} こ$ のことから，対象薬を BID で服用中の患者では QD の患者に比べて服薬アドヒアランスが低くなる ことが予想されたが，治療レジメン群間で過去 7 日 間のアドヒアランス良好率に差は認められなかつ た.このように服薬頻度に関係なく一様に高い服薬 アドヒアランスが認められた背景としては，日本人 特有の勤勉な気質が反映された可能性に加えて, 報 告バイアス（アドヒアランスの過大評価）や思い出 しバイアス（飲み忘れ日数の過小評価）が混入した 可能性は否定できない。 また，そもそも服薬意識の 高い患者に対して BID の治療レジメンが適用され 
Table 5. Factors Related to Low MMAS-4 Scores

\begin{tabular}{|c|c|c|c|c|c|c|}
\hline Item & Category & $n$ & $\begin{array}{c}\text { MMAS-4 } \\
\text { Mean } \pm \text { S.D. }\end{array}$ & $\begin{array}{l}\text { Multivarial } \\
\text { MMAS-4 } \\
\text { LS mean }\end{array}$ & $\begin{array}{l}\text { ble linear regressic } \\
\text { Regression } \\
\text { coefficient, S.E. }\end{array}$ & $\begin{array}{c}\text { on analysis } \\
p \text {-value }\end{array}$ \\
\hline Total & & 970 & $1.0 \pm 0.94$ & & & \\
\hline \multirow[t]{3}{*}{ Regimen } & DPP-4（QD） & 715 & $1.0 \pm 0.93$ & 0.99 & & \\
\hline & DPP-4（BID） & 121 & $0.8 \pm 0.92$ & 0.93 & $-0.04,0.08$ & $p=0.657$ \\
\hline & BG (BID) & 134 & $1.0 \pm 1.01$ & 1.04 & $0.05,0.08$ & $p=0.504$ \\
\hline \multirow[t]{3}{*}{ Age } & $20 \mathrm{yr} \leq,<45 \mathrm{yr}$ & 95 & $1.3 \pm 0.94$ & 1.13 & & \\
\hline & $45 \mathrm{yr} \leq,<65 \mathrm{yr}$ & 463 & $1.0 \pm 0.96$ & 0.93 & $-0.19,0.09$ & $p=0.046$ \\
\hline & $65 \mathrm{yr} \leq$ & 390 & $0.8 \pm 0.91$ & 0.91 & $-0.20,0.10$ & $p=0.054$ \\
\hline \multirow[t]{2}{*}{ Duration of disease } & $<1$ (yr) & 66 & $0.7 \pm 0.85$ & 0.89 & & \\
\hline & $1(\mathrm{yr}) \leq$ & 813 & $1.0 \pm 0.96$ & 1.09 & $0.19,0.10$ & $p=0.062$ \\
\hline \multirow[t]{7}{*}{ Education } & Middle school & 61 & $0.5 \pm 0.67$ & 0.75 & & \\
\hline & High school & 309 & $0.9 \pm 0.91$ & 0.98 & $0.23,0.12$ & $p=0.046$ \\
\hline & Technical school & 69 & $1.0 \pm 0.86$ & 0.98 & $0.23,0.15$ & $p=0.111$ \\
\hline & College & 430 & $1.0 \pm 0.97$ & 1.08 & $0.31,0.11$ & $p=0.006$ \\
\hline & Graduate school & 53 & $1.3 \pm 1.04$ & 1.22 & $0.47,0.16$ & $p=0.003$ \\
\hline & Prefer not to answer & 12 & $0.7 \pm 1.15$ & 1.03 & $0.30,0.27$ & $p=0.262$ \\
\hline & Others & 4 & $0.8 \pm 0.50$ & 0.88 & $0.25,0.42$ & $p=0.555$ \\
\hline \multirow[t]{4}{*}{ Diet and exercise therapy } & No & 67 & $1.0 \pm 0.90$ & 1.12 & & \\
\hline & Diet only & 271 & $1.0 \pm 0.96$ & 1.02 & $-0.09,0.11$ & $p=0.409$ \\
\hline & Exercise only & 85 & $0.9 \pm 0.88$ & 0.90 & $-0.21,0.14$ & $p=0.128$ \\
\hline & Both & 547 & $0.9 \pm 0.95$ & 0.92 & $-0.20,0.11$ & $p=0.071$ \\
\hline \multirow[t]{4}{*}{ Diet habit (skip meals) } & No & 527 & $0.7 \pm 0.85$ & 0.74 & & \\
\hline & 1 meal & 330 & $1.1 \pm 0.92$ & 0.98 & $0.24,0.06$ & $p<0.001$ \\
\hline & 2 meals & 104 & $1.7 \pm 1.01$ & 1.49 & $0.72,0.09$ & $p<0.001$ \\
\hline & 3 meals & 9 & $0.9 \pm 0.60$ & 0.75 & $-0.02,0.28$ & $p=0.939$ \\
\hline \multirow{3}{*}{$\begin{array}{l}\text { Disease and drug literacy } \\
\text { "Do you feel that your condition is getting } \\
\text { better?" }\end{array}$} & No & 147 & $0.8 \pm 0.90$ & 0.91 & & \\
\hline & Yes & 352 & $0.8 \pm 0.86$ & 0.93 & $-0.00,0.08$ & $p=0.976$ \\
\hline & Neutral $^{\mathrm{a}}$ & 470 & $1.1 \pm 0.98$ & 1.13 & $0.20,0.08$ & $p=0.015$ \\
\hline \multirow{3}{*}{$\begin{array}{l}\text { Motivation toward medication } \\
\text { "Missed doses due to not carrying drugs", }\end{array}$} & No & 648 & $0.8 \pm 0.93$ & 0.84 & & \\
\hline & Yes & 258 & $1.4 \pm 0.83$ & 1.39 & $0.55,0.06$ & $p<0.001$ \\
\hline & Neutral $^{\mathrm{a}}$ & 56 & $0.7 \pm 0.76$ & 0.74 & $-0.10,0.12$ & $p=0.406$ \\
\hline \multirow{3}{*}{$\begin{array}{l}\text { Motivation toward medication } \\
\text { "Anxiety toward long-term use" }\end{array}$} & No & 394 & $0.8 \pm 0.87$ & 0.90 & & \\
\hline & Yes & 275 & $1.1 \pm 0.98$ & 1.11 & $0.18,0.07$ & $p=0.009$ \\
\hline & Neutral $^{a}$ & 298 & $1.0 \pm 0.98$ & 0.95 & $0.02,0.07$ & $p=0.764$ \\
\hline \multirow{3}{*}{$\begin{array}{l}\text { Motivation toward medication } \\
\text { "Do not want to take drugs", }\end{array}$} & No & 178 & $0.8 \pm 0.86$ & 1.05 & & \\
\hline & Yes & 670 & $1.1 \pm 0.96$ & 1.12 & $0.06,0.08$ & $p=0.395$ \\
\hline & Neutral $^{\mathrm{a}}$ & 118 & $0.6 \pm 0.85$ & 0.79 & $-0.24,0.10$ & $p=0.023$ \\
\hline \multirow[t]{3}{*}{ Support from medical staffs } & No & 69 & $0.7 \pm 0.85$ & 0.86 & & \\
\hline & Yes & 664 & $0.9 \pm 0.93$ & 1.00 & $0.13,0.11$ & $p=0.225$ \\
\hline & Neutral $^{\mathrm{a}}$ & 229 & $1.2 \pm 0.97$ & 1.11 & $0.24,0.12$ & $p=0.042$ \\
\hline \multirow{3}{*}{$\begin{array}{l}\text { Time constraint } \\
\text { "Missed doses due to a lack of time to refill", }\end{array}$} & No & 722 & $0.9 \pm 0.92$ & 0.88 & & \\
\hline & Yes & 73 & $1.4 \pm 0.97$ & 1.16 & $0.28,0.10$ & $p=0.007$ \\
\hline & Neutral $^{\mathrm{a}}$ & 165 & $1.1 \pm 0.96$ & 0.93 & $0.03,0.08$ & $p=0.681$ \\
\hline \multicolumn{2}{|c|}{ Proportion of days with OTC use (the past 7 days, continuous value) } & 946 & $1.0 \pm 0.95$ & - & $-0.01,0.00$ & $p=0.012$ \\
\hline \multicolumn{2}{|c|}{ Proportion of days with OTC use (the past 30 days, continuous value) } & 938 & $1.0 \pm 0.94$ & - & $0.01,0.00$ & $p=0.017$ \\
\hline \multirow{3}{*}{$\begin{array}{l}\text { Adherence program } \\
\text { "Do you know any adherence programs availa- } \\
\text { ble?" }\end{array}$} & No & 171 & $0.9 \pm 0.98$ & 0.91 & & \\
\hline & Yes, but not using & 599 & $0.9 \pm 0.88$ & 0.91 & $0.01,0.08$ & $p=0.883$ \\
\hline & Already using & 185 & $1.2 \pm 1.07$ & 1.15 & $0.22,0.09$ & $p=0.012$ \\
\hline
\end{tabular}

a Neither agree nor disagree. MMAS-4: Morisky medication adherence scale-4, LS: Least Squares, yr: year, DPP-4: dipeptidyl peptidase-4 inhibitor, BG: biguanide, QD: once daily, BID: twice daily. 
Table 6. Preference on Dosing Frequency

\begin{tabular}{clcccc}
\hline \hline & & \multicolumn{3}{c}{$n(\%)$} \\
\cline { 3 - 6 } & & Total & DPP-4 (QD) & DPP-4 (BID) & BG (BID) \\
& & $n=983$ & $n=725$ & $n=124$ & $n=134$ \\
\hline \multirow{2}{*}{ Preferred frequency } & QW & $325(33.1)$ & $218(30.1)$ & $56(45.2)$ & $51(38.1)$ \\
& QD & $557(56.7)$ & $446(61.5)$ & $45(36.3)$ & $66(49.3)$ \\
& BID & $60(6.1)$ & $26(3.6)$ & $20(16.1)$ & $14(10.4)$ \\
& Unknown & $41(4.2)$ & $35(4.8)$ & $3(2.4)$ & $3(2.2)$ \\
\hline
\end{tabular}

DPP-4: dipeptidyl peptidase-4 inhibitor, BG: biguanide, QW: once weekly, QD: once daily, BID: twice daily.

ていたという選択バイアスも考えられる。しかしな がら，多変量ロジスティック回帰分析により，服薬 行動の指標として広く使用されている MMAS-4 と の関連が検出されたことから，少なくとも過去 7 日 間の PDCC に基づくアドヒアランス評価方法の妥 当性は示唆された。同様に, 過去 30 日間のアドヒ アランス良好率もすべての治療レジメン群で高く, 群間で有意差は認められなかった，ただし，本試験 の服薬アドヒアランス評価では，PDCC が $80 \%$ 以 上を「アドヒアランス良好」，80\%未満を「アドヒ アランス不良」として算出したため, 過去 7 日間の 服薬アドヒアランスの算出の際， 0-1 日の飲み忘れ 日数が許容されるのに対し，過去 30 日間の場合は 0-6 日の飲み忘れ日数が許容されることになる.こ のような手法を用いていることから，過去 30 日で は精度に影響を受け易いとも考えられる。また，過 去 30 日間ではアドヒアランス良好に関連する因子 として MMAS-4 が検出されなかったこと，並びに 上記のバイアスの影響も予想されることから，30 日間という比較的長い観察期間は，患者の記憶に基 づいた自己報告による服薬アドヒアランスの評価に は適当ではなかった可能性がある.

本研究では，MMAS-4 に基づく服薬行動の評価 も実施した. MMAS-4 の平均スコアはいずれの治 療レジメン群においても低值（（1.0）であり， PDCC に基づく評価と同様に，服薬頻度に関係な く高い服薬アドヒアランスが示された。 また今回得 られた MMAS-4 スコアは，MMAS-4 を用いて 2 型 糖尿病患者の服薬アドヒアランスを評価した先行研 究での值と類似しており, 評価は妥当に行われたも のと考察される. ${ }^{18)}$

2 型糖尿病患者の服薬アドヒアランスに関連する 因子として, 年齢や罹病期間, 病識・薬識, 心理的
要因など, いくつかの要因が示唆されている. ${ }^{17)}$ そ こで，PDCC に基づく過去 7 日間のアドヒアラン ス良好に関連する因子を探索したところ，「薬をの まないと病気がひどくなると考える」，「薬の携帯忘 れによるのみ忘れをしない」，「時間的制約がない」 などが検出され。 また，過去 30 日間のアドヒアラ ンス良好に関連する因子についても同様に「薬の携 帯忘れによるのみ忘れをしない」，「時間的制約がな い」などが検出されたことから，服薬に対する意識 が高い患者や薬を受け取りに行くための時間的余裕 がある患者では良好なアドヒアランスが得られ易い 傾向がみられた。 また，「罹病期間が 1 年以上」が 検出された背景としては，罹病期間が長くなるほど 服薬が習慣化され易いことなどが推察される。一方,

MMAS-4 スコア低值，すなわちアドヒアランス良 好に関連する因子を同様に検討したところ，「薬の 携帯忘れによるの夕忘れをしない」，「時間的制約が ない」など過去 7 日間及び過去 30 日間のアドヒア ランス良好に関連する因子と同様の因子が検出され ると同時に，「食事を抜かない」といった生活習慣 に関連する因子も検出された。このことは，逆に不 規則な食事習慣や服薬に対する意識の低さ，忙しい ライフスタイルがアドヒアランス不良につながるこ とを示唆するものと考えられる。また，「服薬補助 のシステムを利用されていますか? “知らない”」 がアドヒアランス良好と関連を示しており，服薬補 助システムに頼らなくとも自律的に服薬が管理でき ている可能性も示唆された.

過去に米国で実施された研究によると，45 歳未 満の比較的若年者では経口糖尿病薬の服薬アドヒア ランスが低いことが確認されている。 ${ }^{19)}$ 本研究で は，アドヒアランス良好又は不良に関する因子とし て年齢は検出されなかったが，サブグループ解析の 
結果， 20 歳以上 65 歳未満の患者の DPP-4（BID） 及び BG（BID）では DPP-4（QD）に比べてアド ヒアランス良好率が低下，若しくは低下する傾向に あることが示された。このことから，65歳未満の 非高齢者では，服薬頻度が重要なアドヒアランス関 連因子になり得ることが示唆された。このことから も，若年者に対してはより手厚い服薬指導を行うこ とや，BID の薬剤を服薬している患者に対し希望 に合わせる形で QD 若しくは QW の薬剤への変更 を提案することも長期的な服薬管理の観点からアド ヒアランスの更なる向上に有効である可能性があ り，今後検証の余地があると考える.

経口糖尿病薬の希望する服薬頻度は，全体では QD が $56.7 \%$ で主要な部分を占めており, QW (33.1\%) よりも高かった。この結果については, DPP-4（QD）を服用中の患者は QD を希望する割 合が $61.5 \%$ と高かったこと，他の治療レジメンに 比べ DPP-4（QD）の症例数が多く，分布に偏りが あった $(5: 1: 1)$ ことに起因したと考える. 一方, DPP-4（BID）及び BG（BID）では，BIDを希望 する患者は 1-2 割弱に留まっているのに対し，QW 及び QD を希望する患者はそれぞれ約 4 割であ り，服用回数が最多である BID を好まない傾向が 示された。先行する患者選好度調查では，約 3 割の 患者が QW を好むとされており，本試験の結果と 一致している. ${ }^{20)}$ 特に, BID で服用中の患者では, 希望通りの服薬頻度で治療を受けられていないこと が明らかになった。ただし，本研究は経口糖尿病薬 を単剂で使用中の患者を対象にしており，併用経口 糖尿病薬のある患者では異なつた結果になる可能性 も考えられる.

本研究では調査対象を DPP-4 (QD), DPP-4 (BID)，又は BG（BID）を単剂服用中の患者に限 定しており，さらに都市・地方での地域差までは調 整できていない（本試験の対象患者の組入が困難で あったことから，県レベルでの均一性が保てなかっ た）ことから，今回の結果をそのまま日本の糖尿病 患者集団全体へ一般化するのは難しいと考えられ る．また，自発的に薬局を訪れ，調査に参加するこ とに同意する患者を対象にしていることから，参加 者の選択バイアスが存在する可能性も否定できな い．前述の通り，本研究は患者の自己報告に基づい た調査であり，報告バイアスや思い出しバイアスの
存在も考慮する必要がある，さらに，臨床検査值の 収集は行っていないため，2 型糖尿病の病態を反映 する検查值やアドヒアランスに影響を及ぼす可能性 のある臨床上の変数を調整できない，以上から，結 果の解釈には一定の限界があると考えられる.

結論

DPP-4 阻害薬又は BG を単剂服用中の 2 型糖尿 病患者では, 服薬頻度にかかわらず高い服薬アドヒ アランスが示された。過去 7 日間のアドヒアランス 良好に関連する因子としては，「罹病期間が 1 年以 上」,「薬をのまないと病気がひどくなると考える」, 「薬の携帯忘れによるのみ忘れをしない」，「時間的 制約がない」などが検出され，罹病期間，病識・薬 識，服薬に対するモチベーション，ライフスタイル などが服薬アドヒアランスに影響を及ぼすことが示 唆された。多変量線形回帰分析で年齢は関連因子と して選択されなかつたものの事後に実施したサブグ ループ解析の結果， 65 歳未満の非高齢糖尿病患者 では，DPP-4（QD）と比較して，BG（BID）でア ドヒアランス良好率が有意に低 $<，$ DPP-4（BID） でも低い傾向が認められた。 また背景因子の集計に より，希望する服薬頻度では $\mathrm{QW}$ 又は $\mathrm{QD}$ を選択 した患者が 8 割以上を占め，特に BID レジメンの 患者では服用中のレジメンとの乘離が認められた. 本研究には一定の限界があるものの，大規模な薬局 調査により日本人 2 型糖尿病患者の服薬行動の一端 が明らかになった。

謝辞 MSD 株式会社との契約の下，本研究の 薬局でのアンケート調查を実施して頂いた株式会社 医療情報総合研究所（JMIRI）の林 裕之氏，来栖 隆雄氏，小林史記氏，JMIRI との契約で本試験の 統計解析を実施頂いた株式会社アスクレップの篠原 正彦氏，碓井英司氏，及び本論文の作成を手伝つて 頂いた株式会社サン・フレアの馬郡慎平氏に心より 感謝いたします。

利益相反本試験は MSD 株式会社により資金 提供された。 MSD 株式会社は試験デザイン，デー 夕解析，結果の解釈，論文執筆，及び公表論文の投 稿を決定した。林 あい（研究実施時：MSD 株式 会社の社員, 現在：AstraZeneca 株式会社の社 
員)。久保武一，奥山ことば，鵫田 滋（MSD 株 式会社の社員)。亀井美和子（MSD 株式会社から 講演料・原稿料・その他の報酬の供与).

\section{REFERENCES}

1) The Japanese Diabetes Society, "The Japanese Clinical Practice Guideline for Diabetes 2016," Nankodo, Co. Ltd., Tokyo, 2016.

2) International Diabetes Federation, "IDF Diabetes Atlas," 8th ed., International Diabetes Federation, Brussels, 2017: 〈https://diabetes atlas.org/resources/2017-atlas.html $\rangle$, cited 8 May, 2018.

3) Kitamura M., JIBI INKOKA TEMBO, 55, 469-472 (2012).

4) Akiyama S., Kayama S., Okabe Y., Watanabe F., Kamei M., Kasahara M., Shinohara K., Jpn. J. Pharm. Diabetes, 3, 180-185 (2014) .

5) Rozenfeld Y., Hunt J. S., Plauschinat C., Wong K. S., Am. J. Manag. Care, 14, 71-75 (2008).

6) Farmer A. J., Rodgers L. R., Lonergan M., Shields B., Weedon M. N., Donnelly L., Holman R. R., Pearson E. R., Hattersley A. T., Diabetes Care, 39, 258-263 (2016) .

7) Pladevall M., Williams L. K., Potts L. A., Divine G., Xi H., Lafata J. E., Diabetes Care, 27, 2800-2805 (2004).

8) Ho P. M., Rumsfeld J. S., Masoudi F. A., McClure D. L., Plomondon M. E., Steiner J. F., Magid D. J., Arch. Intern. Med., 166, 1836-1841 (2006).
9) Cramer J. A., Benedict Á., Muszbek N., Keskinaslan A., Khan Z. M., Int. J. Clin. Pract., 62, 76-87 (2008).

10) Hori T., J. New Rem. \& Clin., 59, 254-259 (2010).

11) Paes A. H. P., Bakker A., Soe-Agnie C. J., Diabetes Care, 20, 1512-1517 (1997).

12) Curkendall S. M., Thomas N, Bell K. F., Juneau P. L., Weiss A. J., Curr. Med. Res. Opin., 29, 1275-1286 (2013).

13) Morisky D. E., DiMatteo M. R., J. Clin. Epidemiol., 64, 262-263 (2011).

14) Kurtyka K., Nishikino R., Ito C., Brodovicz K., Chen Y., Tunceli K., J. Diabetes Investig., 7, 737-743 (2016).

15) Coleman C. I., Limone B., Sobieraj D. M., Lee S., Roberts M. S., Kaur R., Alam T., J. Manag. Care Pharm., 18, 527-539 (2012).

16) Srivastava K., Arora A., Kataria A., Cappelleri J. C., Sadosky A., Peterson A. M., Patient Prefer. Adherence, 7, 419-434 (2013).

17) García-Pérez L. E., Alvarez M., Dilla T., GilGuillén V., Orozco-Beltrán D., Diabetes Ther., 4, 175-194 (2013).

18) Krapek K., King K., Warren S. S., George K. G., Caputo D. A., Mihelich K., Holst E. M., Nichol M. B., Shi S. G., Livengood K. B., Walden S., Lubowski T. J., Ann. Pharmacother., 38, 1357-1362 (2004).

19) Tunceli K., Zhao C., Davies M. J., Brodovicz K. G., Alexander C. M., Iglay K., Radican L., Patient Prefer. Adherence, 9, 191-197 (2015).

20) Sen R., Shields A. L., Atsuda K., J. Health Econ. Outcomes Res., 4, 55-66 (2016). 